\title{
Visual explicitation in intersemiotic translation
}

\author{
Anne Ketola \\ Tampere University, Finland
}

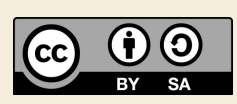

\begin{abstract}
In Translation Studies, explicitation generally refers to an interlingual process where something that is implicit in the source text is made explicit in the target text. This article analyses the concept in an intersemiotic context, focusing on word-to-image translation, with the aim of determining whether word-to-image translation includes meaning construction that could be described as explicitation. The empirical data of the article is a comic contract, a verbal-only document that has been intersemiotically translated into a visual form, i.e. a comic. The analysis concluded that while some of the characteristics described for interlingual explicitation operate with verbal language-specific concepts and cannot be applied to word-to-image translation, other characteristics of explicitation - such as the specification of meaning in translation - seem well-suited for this type of intersemiotic analysis. The analysis also emphasized that distinguishing types of explicitation in word-to-image translation is complicated by the inherent differences of words and images as meaning making resources.
\end{abstract}

Keywords: intersemiotic translation, word-to-image translation, explicitation, illustration, comic contracts

\section{Vizualna eksplicitacija v intersemiotičnem prevodu}

\section{IZVLEČEK}

V okviru prevodoslovja se termin eksplicitacija navadno nanaša na medjezikovni postopek, pri katerem je nekaj izvirniku implicirano, v ciljnem jeziku pa eksplicitno izraženo. V pričujočem član$\mathrm{ku}$ je ta koncept analiziran $\mathrm{v}$ intersemiotičnem kontekstu, pri čemer se osredotočam na prevod besede v sliko, z namenom, da bi ugotovila, ali prevod besede v sliko vsebuje tudi konstrukcijo pomena, ki bi jo lahko opisali kot eksplicitacija. Empirične podatke predstavlja pogodba v obliki stripa, torej besedni dokument, ki je bil intersemiotično preveden v vizualno obliko stripa. Analiza je pokazala, da nekatere značilnosti, ki jih najdemo pri medjezikovni eksplicitaciji, delujejo le z verbalnimi jezikovnospecfičnimi koncepti in jih ni mogoče najti v prevodu besede v sliko, drugi značilnosti eskplicitacije, npr. specifikacija pomena v prevodu, pa se zdijo zelo primerne za tovrstno intersemiotično analizo. Analiza je prav tako pokazala, da je razlikovanje tipov eksplicitacije v prevodu besede $\mathrm{v}$ sliko dodatno zapleteno zaradi inherentnih razlik med besedami in podobami kot pomenotvorni viri.

Ključne besede: intersemiotični prevod, prevod besede v sliko, eksplicitacija, ilustracija, pogodba v obliki stripa 


\section{Introduction}

The concept of intersemiotic translation has been a part of the conceptualization of translational inquiry since the late 1950s (Jakobson 1959). It has attracted persistent research interest over the decades, yet the concept remains somewhat theoretically underdeveloped, especially for word-to-image translation. This article examines one specific type of word-to-image translation, namely the process of converting verbal-only documents into comic-style versions.

Presenting official documents as comics is a practice that has been gaining more and more interest in recent years in different parts of the world (Pitkäsalo and Kalliomaa-Puha 2019, 37-8). The trend originated from South Africa, where lawyer Robert de Rooy developed an employment contract, presented entirely as a comic (a "comic contract"), to be used at a fruit plantation where a large number of the employees had trouble understanding a "traditional", verbal-only contract due to poor language and/ or reading skills (Haapio, Plewe and de Rooy 2016). In a comic contract, the contract parties are presented as visual characters and contract clauses drawn as visual events, often accompanied by diagrams and other visual devices such as calendar views (Haapio, Plewe and de Rooy 2016, 376-377). A comic contract includes verbal text, too (text boxes, speech and think bubbles, and so on), but the text is typically a simplified version of the original (Pitkäsalo et al., forthcoming).

The results gained from de Rooy's comic contract experiment were so promising that the use of comic-style communication soon spread to various fields of practice, such as medicine (e.g. Farthing and Priego 2016; Green and Myers 2010) and technical communication (e.g. Yu 2015). This article reports results from a research project ${ }^{1}$ that is the first to develop comic-style communication for institutional purposes in Finland. The project employs a multidisciplinary group, with an illustrator/comic artist and five researchers, two from Translation Studies (one being the author of this article), one from Legal Research (Social Justice), one from Social Work Research and one from Education Research. The project aims to apply theory from Translation Studies (TS) in order to demonstrate how information changes when it is converted from the verbal into the visual. We set out to test the applicability of translation theory outside the "typical" context of interlingual translation, and to examine and further develop different translation theories in an intersemiotic context.

The data of the article is a comic-style document, an intersemiotic translation of a traditional verbal-only document, produced for the Finnish Federation of Mother and

1 This article is a part of the Word to Image research project (2020-2023), funded by the Kone Foundation. 
Child Homes and Shelters. The document in question is an agreement for a service called supervised exchange. The service entails monitoring situations where a child is transferred from one parent to another after difficult divorces/separations (more detailed description in Section 2.2.1).

A comic-style translation of a verbal-only document, in many ways, offers more detailed information than the original. For instance, where a verbal-only document can refer to the agreement parties simply as "parents" - which may refer to any age, any gender, any race, any physical appearance - the visual translation of this concept needs to be grounded in a concrete visual example of "a parent": a character that looks certain way. In our previous article (Pitkäsalo et al., forthcoming), we have - in passing - proposed that this specification of meaning in intersemiotic translation could be theoretically conceptualized as a type of explicitation. Explicitation is commonly understood as a process of (interlingual translation) where something that is implicit in the source text (e.g. the gender of a "parent") is made explicit in the target text (e.g. Klaudy 2008, 104).

In this article, I examine this idea further. I compare the research literature on explicitation against empirical examples from our project. My research questions are: Are there points of contact between theorical ideas on explicitation in interlingual translation and empirical examples of word-to-image translation? If so, under which conditions could we describe meaning construction in word-to-image translation as explicitation?

This article is structured as follows. Section 2 starts with an examination of the concept of intersemiotic translation, focusing on word-to-image translation, in line with the scope of the article. I reflect on the differences between words and images as meaning-making resources - a matter that informs the empirical reflection conducted in the analysis part of the article. I then introduce the intersemiotic translation process carried out in this particular study. In Section 3, I discuss different approaches to explicitation in TS literature. Section 4 is the empirical part of the article, in which I examine the intersemiotic translation product, the comic-style document, from the perspective of explicitation theory. I reflect on whether explicitation can be said to also take place when the source language (SL) is a verbal language and the target language (TL) is a visual one. Throughout this discussion, I draw attention to the challenges involved in comparing meanings conveyed by two modes that function in fundamentally different ways. Finally, in Section 5 of the article, I summarize the discussion and reflect on the insight that explicitation theory could offer for comic contract production. 


\section{Intersemiotic translation}

This section discusses how intersemiotic translation is understood in this article. I start the discussion by reflecting on the definition and characteristics of intersemiotic translation, focusing on word-to-image translation. I then move on to examine the intersemiotic translation process carried out in this particular study. I introduce the source text, its function and target audience, and then reflect on the characteristics of the intersemiotic translation process: the agents involved, challenges faced and solutions made.

\subsection{Comic-style documents as intersemiotic translation}

In his famous translation typology, linguist Roman Jakobson $(1959,233)$ defined three types of translation:

- Interlingual translation refers to translation as it is typically understood, in other words, conveying the verbal contents of a text written in one language to another language.

- Intralingual translation refers to the "rewording" of a text into a different form by means of the same language.

- Intersemiotic translation, or "transmutation", refers to transferring a message in one sign system to a message in another sign system.

The type of intersemiotic translation discussed in this article is converting verbal signs into visual signs, examining the process of converting a verbal-only document into a comic format. One should point out that research on intersemiotic translation has also been conducted from theoretical and conceptual underpinnings that largely differ from those of the present article. O'Halloran, Tan and Wignell (2016), for instance, examine intersemiotic translation as a process of structuring thought and reality using a variety of semiotic resources. The authors conceptualize intersemiotic translation through the principle of resemiotization; the "translation", as they describe, refers to the conversion of semiotic choices into social practices. This theoretical approach is critically different from that adopted in the present paper: O'Halloran, Tan and Wignell analyze words and images as translations of "thought and reality", whereas this article examines words and images as translations of each other.

The production of comic-style documents also includes intralingual translation operations. The comic includes both text and images. The verbal material used in the comic (in speech bubbles, text boxes and so on) is based on the original, typically complex and jargon-loaded document, and it is intralingually translated into a more 
reader-friendly, colloquial type of expression that in many ways resembles easy-toread language (see, for instance, the speech bubbles in Figure 2). Yet, this article focuses on the intersemiotic dimension of the document translation, in other words, the production of the images as translations of the verbal original.

Intersemiotic translation changes the message that is being translated due to the differences in the ways the two sign systems convey information. Verbal sign systems function in a linear order; words and sentences appear and must be interpreted in a sequential manner. Verbal signs can easily refer backward and forward in time and refer to abstract ideas or concepts that have no physical referents.

Visual sign systems, on the other hand, function holistically and simultaneously: they are available for the viewer to perceive in virtually any order they wish. The viewers may focus on what they find most prominent and/or interesting. Visual expression is grounded in the "present"; it offers very limited means to convey temporality. Referring backward or forward in time can only be done suggestively (for instance, by employing visual symbols such as clocks or calendars or depicting action in a though bubble to convey the idea that the events that are portrayed take place in another temporal dimension). Finally, visual signs are less agile than the verbal in depicting abstract concepts; imagine, for instance, a visual depiction of concepts such as justice or love. When operating within the visual sign system, these concepts need to be grounded in "visual examples" (such as a judge's gavel for justice), which often function as symbols of a sort. Words and images cannot express "the same thing", because they operate on different levels of abstraction.

When a verbal-only document is intersemiotically translated into comic illustrations, there are virtually limitless possibilities for drawing the same scene. The document translated in the present study includes, for instance, a phrase that states that the exchange of the child from one parent to another will not be carried out if the visitation supervisor regards the exchange situation as menacing for the child. The phrase is abstract, as it is meant to cover a variety of situations. The intersemiotic translation starts by grounding this information in a particular example (for instance, a parent arriving for the pick-up in an intoxicated state). This is followed by additional stages of decision making: Which parent is depicted in this state, the mother or the father? What would such a physical state look like in practice (wobbly steps, lack of bodily control, menacing facial expression, speech bubble with growls)? Who else is depicted in the image - the visitation supervisor, a scared child, perhaps? How are they responding to this behaviour in the image? The verbal source material offers a near infinite number of choices for illustration, and the illustrator picks one of these. 


\subsection{The intersemiotic translation process in the present project}

The data of the article is an intersemiotic translation, a comic-style document, produced for the Finnish Federation of Mother and Child Homes and Shelters (hereafter FFMCHS). In this section, I introduce the data production for the study, in other words, describe the source document and the process of translating it into a comic.

\subsubsection{Source text: Function and target audience}

FFMCHS is a nationwide child welfare organization in Finland. It helps children and families in difficult and insecure situations and prevents domestic violence. The federation is the central organization for its 30 member associations. Over 16,000 people use the associations' services every year (Ensi- ja turvakotien liitto, 2020). One of the services that the associations offer is a service for supervised exchanges, needed in difficult divorce/separation situations that involve children, where the separated parents either refuse to see each other, or - when forced to see each other - behave in a way that is painful and stressful for their children. FFMCHS's supervised exchange is a service where one of the parents takes the child into a professionally monitored facility and the other parent picks the child up without the parents having to see each other at all. The use of this service may be ordered by court, or it can be adopted upon the request of (one of) the parents (see e.g. Pitkäsalo et al., forthcoming).

The document that was intersemiotically translated into a comic is what FFMCHS refers to as the Rules and instructions for the supervised exchange service. It is an agreement-like document that dictates when and how the exchanges are to take place: what happens at the FFMCHS facility, what is and is not allowed at the facility, what the client needs to do if they are late for the exchange or have to cancel it, and so on. The parents need to sign the document to indicate their commitment to the rules. At the time of writing the article, the comic contract is still being finished and finetuned, and the images presented in the article are their current versions, still subject to change slightly.

The collaboration between the research team and FFMCHS was initiated by FFMCHS staff members who heard of our team's work and proposed that we recreate one of their documents as a comic, to be used with their clients. According to their staff, they have hundreds of clients who have difficulties understanding the processes based on verbal documentation alone, some due to poor proficiency in Finnish, some due to cognitive challenges. We also suspect that the comic version might allow their child clients to understand the service better. The subsequent stages of our research project involve testing the comic document with the clients of FFMCHS to see if they find it 
useful. Based on the results we receive, FFMCHS will either discard the comic version, or adopt it for their use, either providing it as an additional, explanatory attachment to the traditional, verbal-only document, or having the comic version replace the traditional document altogether.

\subsubsection{Target text: From words to images}

The intersemiotic translation process of the document was carried out as a team effort. The process unfolded in an iterative manner: after initial negotiations within the six-person research team, the illustrator created a first draft of the illustrations, which was then taken up for discussion with the research team members and modified twice. The draft was then presented to representatives of FFMCHS and modified according to their feedback. In other words, the translation process was a collaborative effort; over ten people were involved in making the decisions that would dictate the overall visual solutions.

One of the challenging things in the translation process was the depiction of the human characters. The decision making related to this involved various stages. The first step was to decide how many human characters would be included in the comic, and which ones. There are no correct answers to this question; different "characters casts" enable different visual perspectives to be taken into the contract contents. With this comic, our decision was to include two parents, one child and one exchange supervisor who represents FFMCHS in the comic (the characters are shown in Figure 1 below).

Our previous, shorter pilot version of the document, illustrated by a different illustrator, included two parents and two children; an exchange supervisor was not included as an illustrated character, but as "a narrator voice", speech bubbles coming from outside the actual comic page. Even though this solution worked well, too, the structural solutions we wanted to include in the current version seemed to require the character to be drawn: the current version of the comic includes various scenes in which the supervisor is an essential participant. The piloting version of the comic included two children, and our new version only one - for the simple reason that this made the comic easier to illustrate, as there were less things to draw.

After deciding the number of the characters to be included in the comic, the following questions were: What do the characters look like, and how do they interact with each other? The source text, the verbal-only document, does not (need to) comment on the agreement parties' gender, race or any other dimension of their physical appearance, nor does it comment on how they appear to feel when set in the situations outlined by the contract. Are they content, worried, or happy? What is the relationship like between a parent and the child? 
The research team decided to include a heteronormative family, with a female-looking character as the mother and a male-looking character as the father. This visual solution obviously does not represent all families, but we deducted that this gender-division would be relatable for most of the clients of the service. The verbal text that is included in the comic still only refers to these characters as "parents", not as the "mother" and the "father", but the visual gender representation overrides this neutrality from the perspective of the comic reader.

Further, our team decided to depict the family as white/Caucasian. In principle, one could say that the visual image of a while heterosexual family is an old-fashioned, outmoded stereotype. However, the contract also touches upon possible alcohol or drug abuse of the parents, and the team felt that - in a country with predominantly Caucasian population - presenting the (potentially) addict parents as anything else but white might end up fostering racist interpretations.

We aimed to represent the child and the exchange supervisor in a way that avoids non-binary gender depiction. In our research team discussions, however, we have noticed that some of our team members regard the child more as a boy than a girl, although the goal was neutrality. The question of gender representation is one of the central things to examine in the reception research part of our research project, yet to be initialized.

In the iterative comic production process, in the feedback we received from FFMCHS representatives regarding the visual depiction of the characters, three modification requests were presented. They requested that that the overall depiction of the exchange facility would be slightly cozier and friendlier than in our initial version (which concretized in, among other things, making the characters smile more). The motive behind this request was that they hoped that a friendly-looking comic would help dispel some of the concerns their clients have prior to starting the service: the whole procedure sounds strange and even intimidating to many. This is an interesting sub-agenda, and it could be said to echo different types of manipulation that may take place in intralingual translation. Their other modification requests included making the child character slightly older and possibly adding another child, since some of their child clients are older and some of the families have more children. However, the research group decided not to carry out these changes. No visual solution covers all types of families, so the modification did not seem worth the illustration resources - illustration is a time consuming process, and hence an expensive one.

The point I have aimed to make with this process description is that with this type of word-to-image translation, the source text itself does not offer right answers as to how it is to be translated in practice. The source text is abstract and allows for different visual concretizations. The translation - the illustrations - are one possible 
interpretation of what the source text "means". In the following sections of the article, I move on to discuss whether this concretization can be theoretically conceptualized as explicitation in intersemiotic translation, and what type of a shared understanding of explicitation that would require.

\section{Explicitation in Translation Studies}

In this section of the article, I discuss some of the influential ideas that have been introduced on explicitation in translation. My discussion does not aim to be a conclusive account of explicitation theory, but a reflection on whether some of the ideas proposed within explicitation theory could be applied to intersemiotic translation, and word-to-image translation in particular.

The following section touches upon the work of Vinay and Darbelnet (1958), Blum-Kulka ([1986] 2000) and Klaudy (2008) as well as Klaudy's work published together with Károly (2005). I refer to this material as research on explicitation in interlingual translation. I should emphasize that none of these studies explicitly claim to focus on interlingual translation alone, but given the all-interlingual nature of the data these studies build their ideas on, I assume that the arguments that are made principally aim to cover interlingual contexts alone.

In short, explicitation in translation refers to some type of information addition. As described below, in some definitions, the addition refers to content-related lexical elements; in others, it is related, for instance, to the cohesiveness and coherence of the TT. Some explicitation theories distinguish between addition that happens inevitably due to the differences between the expressive means of SL and TL, and addition that happens because of the translator's deliberate decisions. In other words, no consensus exists in TS as to how explicitation should be defined.

Vinay and Darbelnet (1958) were the first to introduce the concept of explicitation in TS. They described explicitation as

"a procedure that consists in introducing in the target language details that remain implicit in the source language, but become clear through the relevant context or situation" (Vinay and Darbelnet 1958, 9; English translation from Titik Murtisari 2016, 67)

Among other early theoretical advances, Blum-Kulka ([1986] 2000) viewed explicitation as shifts that affect cohesiveness and coherence at the TT discourse level. Blum-Kulka ([1986] 2000, 312) distinguishes between "optional" and "obligatory" shifts: optional shifts being those that are "attributable to stylistic preferences" and obligatory 
shifts being those that are "dictated by the grammatical systems of the two languages". In Blum-Kulka's ([1986] 2000, 300) view, explicitation results from "the process of interpretation performed by the translator on the source text", in other words, "the translation process itself" and proposes that explicitation may be universally inherent in all translation (302).

Building on Blum-Kulka's work, Klaudy (2008) proposed an explicitation typology that displays the following categories of explicitation:

1. Obligatory explicitation caused by lexico-grammatical differences between SL and TL.

2. Optional explicitation caused by "differences in text-building strategies [...] and stylistic preferences between languages" (Klaudy 2008, 83), hence pointing out that a TT can be grammatically correct, yet clumsy and unnatural for TL readers. This concept is, therefore, slightly more specific than that of optional shifts proposed by Blum-Kulka, which - in their brief description - can be interpreted to refer to the stylistic preferences of the translator.

3. Pragmatic explicitation motivated by differences in cultural and/or world knowledge of SL and TL readers.

4. Translation-inherent explicitation which "can be attributed to the nature of the translation process itself” (Klaudy 2008, 83).

Klaudy's subsequent research (Klaudy and Károly 2005) discusses explicitation and implicitation from the perspective of the (a)symmetry of the relationship between the transfer operations from a specific SL to a specific TL. Klaudy and Károly $(2005,15)$ provide examples of what constitutes explicitation:

- "when a SL unit with a more general meaning is replaced by a TL unit with a more specific meaning"

- "when the meaning of a SL unit is distributed over several units in the TL"

- "when new meaningful elements appear in the TL text"

The authors also present examples of explicitation dealing with phrase/clause level changes, but these are not included here, since the TT examined in this article is in image-form. Perhaps the most interesting theoretical advance put forward in Klaudy and Károly's article is what they refer to as the asymmetry hypothesis: The authors propose that the translation between certain languages involves operational symmetry, meaning that "explicitation takes place in one direction, while implicitation occurs in the opposite direction" $(2005,18)$. Further, the authors propose that with certain language pairs, "explicitation in one direction is not counterbalanced (paralleled) by implicitation in 
the opposite direction", referred to as operational asymmetry (ibid.). The idea of analyzing the hypothesis in the context of intersemiotic translation is extremely tempting; however, it falls outside the scope of this article since the material examined here only involves one translation direction (from word to image). Still, it is touched upon in the conclusion section of this article by reflecting on future research directions.

\section{Analysis: Visual explicitation in the word-to-image translation}

In this section of the article, I compare the above discussion on explicitation in interlingual translation to empirical examples of our intersemiotic translation endeavour, namely the translation of a verbal-only agreement document into a comic. My focus is on the intersemiotic, the translation of words into images; the intralingual is left outside of this analysis. The challenges involved in comparing meanings conveyed by two modes that function in fundamentally different ways motivate the discussion throughout.

My analysis will focus on four theoretical characteristics of explicitation that, in one way or another, resonate with my observations of this particular intersemiotic translation. I will start by reflecting on specification of meaning in word-to-image translation, analysing the visual depiction of the comic characters as a simple example (e.g., the word "parent" vs. drawing of a "parent"). I then reflect on the type of explicitation where the "meaning of a SL unit is distributed over several units in the TL" (Klaudy and Károly 2005), which invites a more thorough reflection on what we mean by "units" of meaning in an intersemiotic context of this kind. What are the "chunks" of information we compare for explicitation when we go beyond simple examples? After this reflection, I move on to analyze potential lexical and pragmatic increase in wordto-image translation, followed by a discussion on how the idea of stylistic choices in explicitation relate to word-to-image translation.

\subsection{Specification of meaning in explicitation}

The visual depiction of the comic characters appears to be an example of the type of explicitation in which a SL unit with a more general meaning is replaced by a TL unit with a more specific meaning (cf. Klaudy and Károly 2005, 15). The intersemiotic translation of the characters gives them a more specific form of representation. The verbal SL unit "child", for instance, visually becomes a particular child, of a particular age (range). Consider Figure 1. 

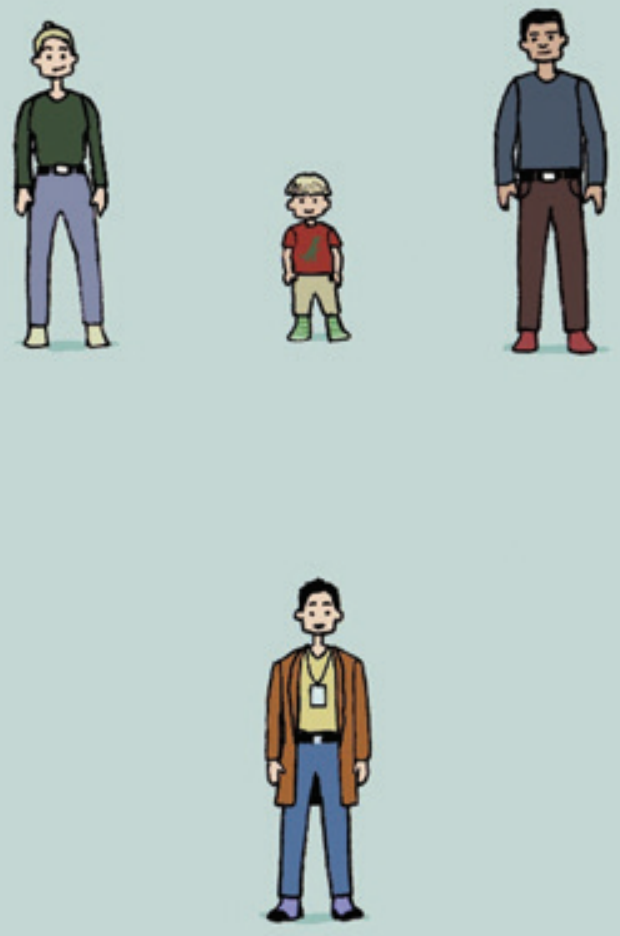

Figure 1. An example from the data: The characters of the comic contract introduced on the first page of comic document. In the final comic production phases, text will be added on the page that designates the characters, from left to right (top row), as "Parent 1", "Child", "Parent 2", and, on the bottom row, as "Exchange supervisor".

Whilst the verbal text designates the parents (the agreement parties) simply as "Parent 1" and "Parent 2", their visual representation assigns them with a gender. Further, their visual representation assigns them with a certain physical appearance, including racial characteristics. The gender and the physical appearance can be described as "details that remain implicit in the source language" (cf. Vinay and Darbelnet's definition introduced above) but become more explicit in the target language (the image). From the perspective of the reader of the comic document, the visual explicitation of the comic characters is potentially problematic: the readers might experience difficulties in relating to the document contents if they cannot identify with the way the characters are visually depicted (for instance, if the document readers do not represent a heteronormative family or if they represent a different race). 
Further, the document includes information about the actions of a "parent"; for instance, the rather negative example discussed in Section 2.1 ("the exchange of the child from one parent to another will not be carried out if the visitation supervisor regards the exchange situation as menacing for the child"), which, in our comic version, has been intersemiotically translated as an image of "Parent 2", the father, arriving for the pick-up in an intoxicated state. The solution is an example of specification of meaning on several levels. First, the generic idea of "a menacing situation" has been visually specified as a parent being intoxicated - according to the FFMCHS representatives, this would be a typical example of such a situation, but it could also be something else. The visual rendering of the menace might even interfere with other possible interpretations from the comic reader's perspective. Second, the visual translation specifies which parent is the intoxicated one in this imagined scenario. Whichever parent is selected for the image, the solution is potentially insulting for some of the readers.

To conclude, the comparison of verbal and visual information in this example does indeed resemble a type of explicitation in translation, namely specification of meaning. However, Figure 1 is a fairly simple example of a combination of verbal and visual information. Here, comparing SL and TL "items", is easy: we compare an individual word of the ST ("parent") with a simple drawing in the TT ("drawing of a person representing a parent"). However, the comparison is more complicated when the compared chunks of information are more elaborate. This becomes evident in the following example.

\subsection{Distribution of meaning in explicitation}

I now move on to reflect on Klaudy and Károly's second explicitation example, namely explicitation as an operation where the meaning of a SL unit is distributed over several units in the TL $(2005,15)$, and reflect on this in the intersemiotic framework of wordto-image translation. This discussion, obviously, requires us to have a shared understanding of what exactly we mean by units. Due to the modal differences in the expressive potential and expressive means of the two modes, discussed in Section 2.1, verbal expression is easier to segment into "units" (words, clauses, sentences, etc.) than visual expression. The visual functions holistically - it is both the details and the whole at once. For this reason, we do not always have a one-to-one correspondence between a verbal unit such as a word and a clearly distinct, visual chunk. The visual distributes meaning over individual visual items inside comic panels, the panels as individual items, comics constituting several panels, possibly a comic page constituting several strips, and so on. The intersemiotic translation presented in Figure 2 offers examples of this. 

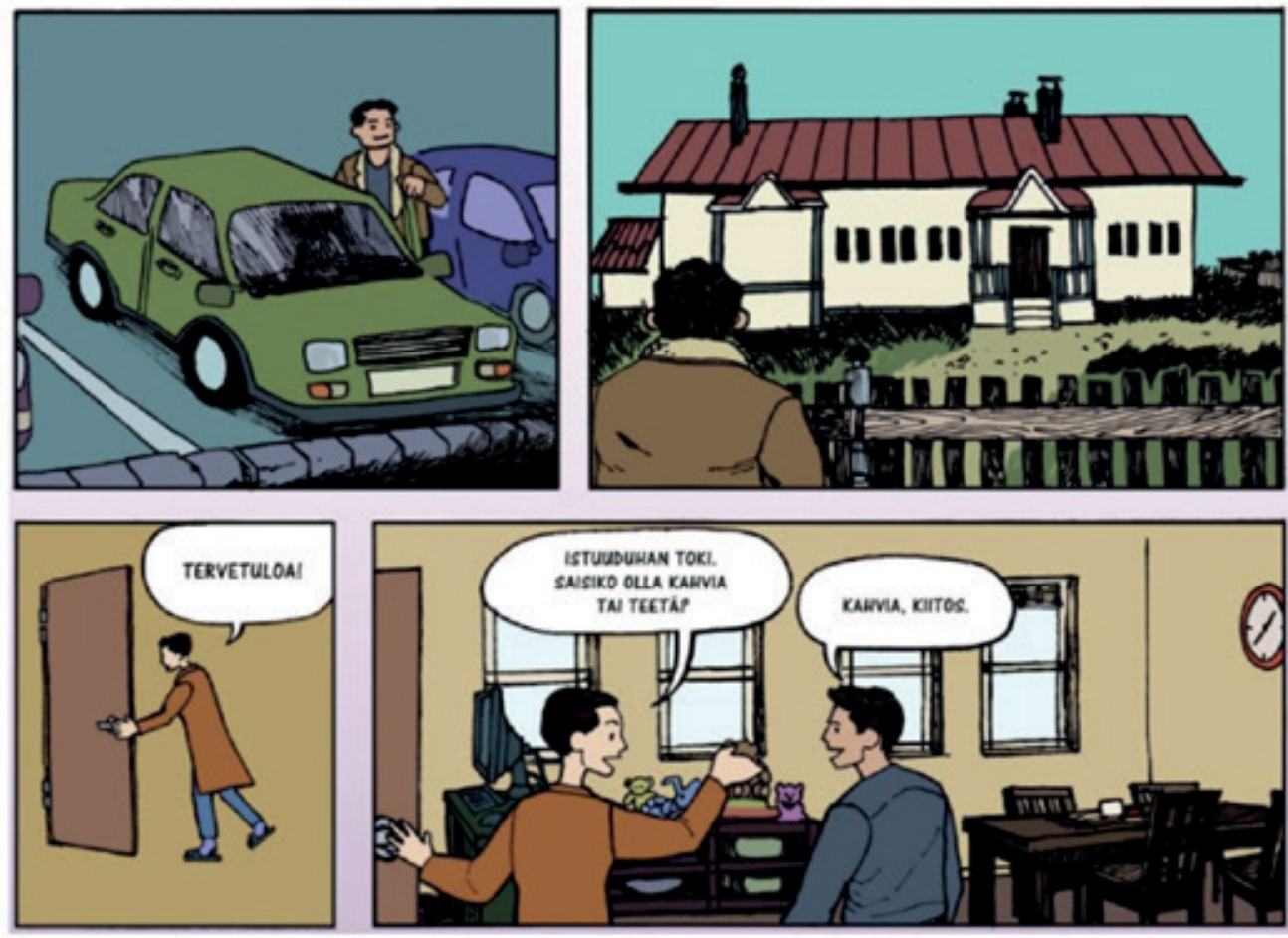

Figure 2. An example from the data: Four consecutive panels that describe a situation where a parent would come to visit the exchange facility prior to starting the exchange service.

Figure 2 includes four consecutive comic panels that constitute the intersemiotic translation of the phrase "Ennen ensimmäisen vaihdon järjestämistä molemmat vanhemmat sekä lapset tutustuvat tapaamispaikkaan [Both parents and the children visit/ get to know the exchange facility before the first supervised exchange takes place]." The first panel presents a person - who has previously been introduced as the father/ Parent 2 - getting out of a car in a parking lot. The second presents the man with his back to the viewer, standing in front of a building. The third presents a person who has previously been introduced as the exchange supervisor - opening a door, articulating in a speech bubble the word "Tervetuloa! [Welcome!]". The fourth panel presents the two people inside a room; the supervisor articulating, "Istuuduhan toki. Saisiko olla kahvia tai teetä? [Please sit down. May I get you some coffee or tea?]" and the father responding, "Kahvia, kiitos [Coffee, please]."

In this is example, the meaning conveyed by a single phrase in the ST is distributed over several comic panels. We cannot say which panel would correspond to which part of the sentence; the ST information is distributed over all of them. We can also 
say that the meaning a single word, "the facility", is distributed over several panels: if we look at the comic, the "facility" is visually presented in the last three panels. We first see the building from the outside, then from the inside.

Is this an example of having "the meaning of a SL unit being distributed over several units in the TL", then? This would depend on our definition of a visual unit. If one were to equal visual unit with comic panel, for instance, the answer to the question would be 'yes'. If one wants to acknowledge the holistic nature of visual communication in a broader sense - if we regard the strip (or an entire comic page, or a spread, or even the entire comic) as one large, multifaceted visual meaning unit - the answer would be 'no'. Both ways of approaching the visual have their pros and cons. The former (segmenting the visual) might be analytically easier, but the latter (examining the visual holistically) might have a more solid theoretical basis.

After concluding this, we may want to revisit the example presented in Section 4.1, discussing the individual comic characters. If we acknowledge the holistic nature of a comic reader's interpretation, we should take into consideration that the idea the reader constructs of, for instance, "Parent 2" based on the TT is not limited to the first illustration in which the character is presented (Figure 1). In interlingual translation, a reoccurring verbal item (such as "parent" repeated various times in a ST) would typically be translated with the same equivalent throughout the TT, for consistency. In an intersemiotically translated comic, on the other hand, the translations of the reoccurring item can differ in appearance. "Parent 2 ", for instance, is intersemiotically translated in slightly different ways throughout the TT - in the panels presented Figure 2, for example, the readers see the character interacting with others in a friendly manner. All these instances are likely to elaborate on an overall interpretation of the character. All of the intersemiotic translations of "Parent 2" are individual examples of specification of meaning, and together they further specify each other.

\subsection{Explicitation as lexical and pragmatic increase}

I now move on to consider how types of increase mentioned in explicitation literature would compare to meaning construction in word-to-image translation, examining ideas on lexical increase first. In a strict sense, one could argue that even if something is deliberately added in word-to-image translation, it cannot be viewed as lexical increase because grammatical comparison in a quantifying sense across modes is not viable. Even if we did adopt an idea of a "visual grammar" (cf. Kress and van Leeuwen [1996] 2006), the two modes are incommensurable in that one cannot plausibly measure and compare the "quantity" of content conveyed by each; at least, not in the degree in which we can do this in interlingual translation. It would appear that the theoretical 
lens of lexical increase in explicitation (based as it is on a "modally specific" concept of lexicality) does not directly lend itself for intersemiotic comparison.

The "content additions" made in word-to-image translation could, however, be conceptualized with Klaudy and Károly's $(2005,15)$ idea of explicitation as a process where new meaningful elements can appear in the TL text. Our data includes countless examples of "new meaningful elements" that have appeared in the TT, ranging from tiny details to larger things. In order to create a comic that is visually enjoyable - a product that looks engaging - an environment is added to the events that take place (instead of simply presenting the characters against a white background). A great deal of visual detail goes into the depiction of this environment. Consider, for instance, the fourth panel in Figure 2, presenting a view from the inside of the exchange facility. There are toys in the background. As a visual element, the toys are meaningful: they function towards constructing an image of the exchange facility as a warm, child-friendly place (their inclusion in the image actually stems from the request of FFMCHS staff to make the facility look "friendly" in the comic, discussed in Section 2.2 of the article). The ST, as a straightforward institutional text, carries no such meanings. Of course, not all of the added environment details in the illustrations carry an agenda of this sort - most of the visual environments are simply made up by the illustrator. Yet all of the details have the potential to carry meaning for the reader.

Pragmatic increase is also named as a characteristic of explicitation in interlingual translation. Klaudy's ([1998] 2008) pragmatic explicitation category shifts the attention to ST and TT readers, and possible differences in their cultural and/or world knowledge. With the document that constitutes the data of this article, in a very direct sense, the readership of the two is the same: the TT is meant to replace the document the clients would otherwise read (the ST). While it might not be possible to pinpoint individual, practical examples of pragmatic explicitation in this translation, one could propose that the whole act of having the complex verbal document translated into a reader-friendly comic is a pragmatic consideration of the target readership; the whole thing, in a sense, is a pragmatic explicitation of information.

\subsection{Stylistic choice in explicitation}

The idea of obligatoriness versus optionalness is included in both Blum-Kulka's and Klaudy's reflection on explicitation; both discuss it in reference to stylistic solutions. As commented on above, the difference in the two researchers' take on the terms is that Blum-Kulka regards optional explicitation as a translator's preferences on stylistic solutions. In Klaudy's thinking, optional explicitation refers to stylistic preferences between languages, in other words, creating the translation in a way that best 
conforms to the stylistic means of a particular language. I argue that neither of these ideas is directly applicable to the intersemiotic context of word-to-image translation. Of course, we can consider stylistic solutions in the sense of what makes an illustrator's art unique (a style of illustration). One artist's rendering of a comic-style document would, naturally, always be at least slightly different from another's, given that artists have different illustrations styles.

Yet I argue that this "artistic-stylistic" consideration in word-to-image translation is not directly related to explicitation, because it is not related to the degree of information conversion. For instance, selecting a character for illustration (a content decision) falls under explicitation, but what does not constitute explication is whether the character's head is made perfectly round or an oval shape (a stylistic decision) in the image. Neither the round nor oval head is more explicit than the other. The explicitation-related decision making, in principle, precedes artistic-stylistic choice.

\section{Conclusions}

This article set out to analyze whether word-to-image translation includes meaning construction that could be described as explicitation. This was done by tracing possible points of contact between theorical ideas on explicitation in interlingual translation and examples of word-to-image translation, selected from data of a comic-style translation of a verbal-only document.

In short, my analysis concluded that some of characteristics and features that have been proposed for explicitation in interlingual translations seem to also apply for word-to-image translation, but not all. Many of the characteristics described for interlingual explicitation operate with verbal language-specific concepts such as lexicality and cannot be applied to intersemiotic contexts such as word-to-image translation, simply because lexicality is not a feature of the visual mode. Further, my analysis emphasized that distinguishing forms of explicitation in word-to-image translation is complicated by the inherent differences of words and images as meaning making resources. The most profound difference and complicating factor is perhaps that - with visual products as elaborate as comics - we do not typically have a one-to-one correspondence between a verbal unit such as a word and a clearly distinct, visual unit. Analyzing explicitation involves examining how meaning is transferred from the ST to the TT and, and the complex distribution of meaning in the TT, a multi-part visual medium, does not always lend itself for clear-cut comparison.

However, on a higher level of abstraction, moving beyond pinpointing individual bits of information, the recreation of meaning in word-to-image translation does share 
some characteristics with how interlingual explicitation is theoretically described. The verbal mode can effortlessly express abstract concepts, for instance, in a precise, unambiguous manner. While images, too, can be used in a highly abstract manner (consider, for instance, abstract visual art), the visual mode less often lends itself to being both abstract and unambiguous. For this reason, a reader-oriented visual medium such as a comic contract typically employs clear, precise drawings. For instance, the people that are mentioned in the ST are labelled in a very generic way. Yet, in the intersemiotic translation, they have to be presented as concrete visual examples of specific people with specific physical characteristics; their depiction goes from implicit to explicit. The TL depiction of the people is less open for a range of interpretations.

In addition to the specification of meaning in word-to-image translation, my analysis also showed this type of translation easily results in new meaningful elements appearing in the TT. Further, explicitation where the meaning of a SL is distributed over several units in the TL could also be described as a feature of word-to-image translation, provided that we employ a definition of a TL unit that permits such a quantifying comparison. If we examine explicitation through these features alone, we could propose that when intersemiotically translating verbal-only documents into comics, explicitation is indeed a translation-inherent feature that results from "the process of interpretation performed by the translator on the source text" (cf. Blum-Kulka [1986] 2000, 300; emphasis added), whilst acknowledging that, in practice, this interpretation is typically negotiated between various people who participate in the process.

The information that is specified in or added to the TT is not something that unequivocally exists in the source text. Instead, it is the translator's/ team's interpretation of what a more explicit representation could be like. When only a fragment of possible interpretations can be included in the image, the creator(s) of the intersemiotic translation will always (either consciously or not) prioritize certain things over others. The decisions that are made emphasize certain aspects of the ST and downplay others; they support certain interpretations and make others less prominent. This is exactly why, I argue, translation theory has a lot to offer for the analysis of comic-style documents such as comic contracts, which aim for neutrality. An explicitation analysis can benefit the creators of comic-style documents in making explicit - pun intended - the degree of decision making and content transformation involved.

This article has aimed to provide a preliminary reflection on the concept of explicitation in an intersemiotic context, focusing on word-to-image translation. The topic offers a wealth of directions for further examination, ranging from analyzing the phenomenon with different types of word-to-image translation data, as well as looking at it in the context of other types of intersemiotic translation, such as image-to-word 
translation (audio description, for example). One possible research direction could also be the examination of the asymmetry hypothesis in the context of intersemiotic translation: if explicitation takes place in one translation direction, could it be that implicitation occurs in the opposite direction? All in all, there is a lot of room for theoretical development in the scope of intersemiotic translation.

\section{References}

Blum-Kulka, Shoshana. (1986) 2000. "Shifts of Cohesion and Coherence in Translation." In The Translation Studies Reader, edited by Laurence Venuti, 298-312. London and New York: Routledge. First published in Intercultural Communication: Discourse and Cognition in Translation and Second Language Acquisition, edited by Juliane House and Shoshana Blum-Kulka, 17-35. Tübingen: Narr.

Ensi- ja turvakotien liitto. 2020. "Eroauttaminen." Accessed March 12, 2021. https://ensijaturvakotienliitto.fi/tietoa-liitosta/nain-me-autamme/eroauttaminen/

Farthing, Anthony, and Ernesto Priego 2016. "Graphic Medicine' as a Mental Health Information Resource: Insights from Comics Producers." The Comics Grid: Journal of Comics Scholarship, 6 (1): 1-23. https://www.comicsgrid.com/article/id/3529/.

Green, Michael J., and Kimberly R. Myers. 2010. "Graphic Medicine: Use of Comics in Medical Education and Patient Care." The Veterinary Record: Journal of the British Veterinary Association. 166 (11): 574-77.

Haapio, Helena, Daniela Alina Plewe, and Robert de Rooy. 2016. "Next Generation Deal Design: Comics and Visual Platforms for Contracting." In Networks. Proceedings of the 19th International Legal Informatics Symposiom IRIS 2016, edited by Erich Schweighofer, Franz Kummer, and Walter Hoetzendorfer, 373-380. Wien: Österreichische Computer Gesellschaft OCG.

Jakobson, Roman. 1959. “On Linguistic Aspects of Translation.” In On Translation, edited by Reuben Brower, 232-39. New York: Oxford University Press.

Klaudy, Kinga. 2008. "Explicitation." In Routledge Encyclopedia of Translation Studies, edited by Mona Baker and Gabriela Saldhana, 80-5. London: Routledge.

Klaudy, Kinga, and Krisztina Károly. 2005. "Implicitation in Translation: Empirical Evidence for Operational Asymmetry in Translation." Across Languages and Cultures 6 (1): 13-28.

Kress, Gunther, and Theo van Leeuwen. 2006. Reading Images. The Grammar of Visual Design. 2nd ed. London: Routledge.

O’Halloran, Kay L., Sabine Tan, and Peter Wignell. 2016. "Intersemiotic Translation as Resemiotisation: A Multimodal Perspective." Signata 7: 199-229.

Pitkäsalo, Eliisa, and Laura Kalliomaa-Puha. 2019. "Democratizing Access to Justice: The Comic Contract as Intersemiotic Translation." Translation Matters 1 (2): 30-42. 
Pitkäsalo, Eliisa, Anne Ketola, Vaula Haavisto, and Laura Kalliomaa-Puha. (forthcoming). "Image Analysis as a Visualization Tool - Translating Contracts into Comics." In Research Handbook on Contract Design, edited by Marcelo Corrales, Helena Haapio, and Mark Fenwick. Cheltenham, UK: Edward Elgar Publishing.

Titik Murtisari, Elisabet. 2016. "Explicitation in Translation Studies: The Journey of an Elusive Concept." Translation \& Interpreting 8 (2): 64-81.

Vinay, Jean-Paul, and Jean Darbelnet. 1958. Stylistique comparée du français et de l'anglais. Paris: Didier.

Vinay, Jean-Paul, and Jean Darbelnet. 1995. Comparative Stylistics of French and English: A Methodology for Translation. Translated and edited by Juan C. Sager and Marie-Josee Hamel. Amsterdam and Philadelphia: John Benjamins.

Yu, Han 2015. The Other Kind of Funnies: Comics in Technical Communication. New York: Baywood Publishing Company.

\section{About the author}

Dr. Anne Ketola is a post-doctoral researcher at the Faculty of Social Sciences at Tampere University, Finland. Ketola works for the Word to Image research project (2020-2023), which produces and examines comic-style versions of complex, institutional documents. Her prior research examines multimodality in translation, focusing mainly on word-image interaction in the translation of illustrated texts. In her $\mathrm{PhD}$, she cognitively modelled how illustrations affect verbal text comprehension in technical translation. 